\section{Identity of Polystictus( $=$ Polyporus = Trametes) cinnabarinus (Jacq.) Fr. with Polystictus sanguineus (L.) Fr.}

Externally, sporophores of the two species, Polystictus cinnabarinus and $P$. sanguineus, differ in the tint of red coloration and in the nature of the porous areas, though they are regarded by many as identical. Miss Wakefield holds (personal communication, 1948) Polystictus sanguineus as the tropical country-analogue of Polystictus (Trametes) cinnabarinus of the temperate climate. Cunningham ${ }^{1}$, in his recent revision of Australian Polyporaceæ in herbaria of the Royal Botanic Gardens, Kew, and of the British Museum (Natural History), holds Polyporus (Coriolus) sanguineus Fr. to be identical with Polyporus cinnabarinus Fr., with the remark that "there is no constant feature upon which two species may be maintained". Cleland $^{2}$ is also of the same opinion, as he noticed fruit bodies of Polystictus sanguineus and Polyporus cinna barinus growing in the same area of Sydney, almost at any time of the year after sufficient rain, on fallen logs. Lloyd ${ }^{3}$ holds Polystictus cinnabarinus as the temperate region-analogue of the tropical Polystictus sanguineus.

Cultural characters of the two species in malt extract-agar slants, however, show important and constant differences between the two. The hyphæ of $P$. sanguineus usually soon develop red pigments ${ }^{4}$ on their walls, and the whole slant looks mainly grenadine red, and scarlet red, scarlet or Brazil red afterwards ${ }^{5}$, while the vegetative hyphæ of $P$. cinnabarinus remain perfectly uncoloured; only the porous areas, when eventually formed with development of basidiainitials, take on the characteristic Morocco red, scarlet, scarlet red, and Brazil red colour ${ }^{5}$.

On pairing cultures of the two species on maltagar-coated slides no hyphal fusion between the two could be observed; the hyphæ of the two colonies passed along each other without any fusion and there were abundant coilings (anti-clockwise under the microscope) of some hyphal branches of both, showing distinct inhibition as remarked by Brian et al. ${ }^{6}$. If there were thicker coatings of malt agar on slides, there appeared a distinct line of aversion between the two. Malt extract-agar plates were inoculated on the same

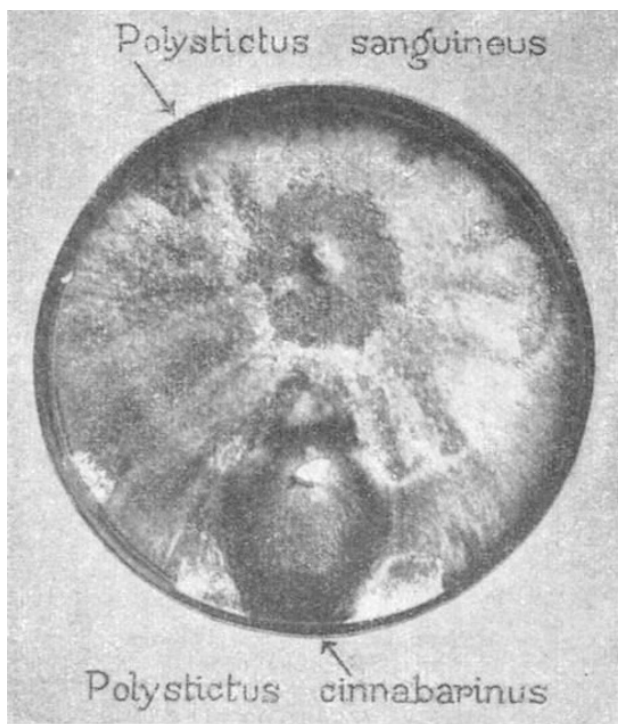

day by the disk method with cultures of $P$. sanguineus and $P$. cinnabarinus on two sides of the plate at a distance of $3 \mathrm{~cm}$. from each other. In the course of three days $P$. sanguineus, being a faster grower, surrounded the colony of $P$. cinnabarinus, leaving a visible distinct zone of aversion all round (see accompanying illustration). Microscopical examination of both aerial and submerged mycelium at the zone of aversion showed hyphæ of both species crossing each other with no hyphal fusion anywhere and with very pronounced anti-clockwise coiling of some hyphal branches of both.

From these characters it is concluded that the two species are distinct and are not identical, as held by previous workers.

Botanical Laboratory,

Carmichael Medical College, Calcutta.

Sept. 16.

${ }^{1}$ Cunningham, G. H., Proc. Linn. Soc. New South Wales, 75, 240 (1950).

${ }^{2}$ Cleland, J. B., J. Proc. Roy. Soc., N.S. Wales, 51, 485 (1918). "Toadstools and Mushrooms and other Larger Fungi of South Australia",

Lloyd, C. G., Mycol. Notes, 6, 1270 (1924).

- Bose, S. R., Trans. Nat. Inst. Sci. India, 2, 69 (1941).

s Ridgway, R., "Color Standards and Color Nomenclature" (Washington, D.C., 1912).

- Brian, P. W., et al., Trans. Brit. Mycol. Soc., 29, 185 (1946).

\section{Enhancement of Streptococcal Bacteriophage Lysis by Hyaluronidase}

IT is well known that most Group A streptococci synthesize hyaluronic acid, which forms the streptococcal capsule, during the early stages of growth, and that mucoid colonies on blood agar are formed by strains that produce considerable amounts of hyaluronic acid. During attempts to propagate bacteriophages active against Group A streptococci, it was found that the organisms which survived and gave secondary growth were invariably mucoid. This observation suggested that the hyaluronic acid capsule might form a barrier between the organism and the bacteriophage and prevent attack. If this were so, then the inclusion of hyaluronidase in the medium might be expected to prevent the formation of a capsule and leave the organism vulnerable to attack by the bacteriophage.

Tests were made to find the smallest amount of purified hyaluronidase (Bengers) which prevented capsule formation in serum broth. In the subsequent tests with phages, five times this concentration was used.

Two phages, which ordinarily gave only partial clearing in broth, were added, together with their respective propagating strains, to plain serum broth containing hyaluronidase. The tubes were incubated for $15 \mathrm{hr}$. Those tubes containing hyaluronidase showed complete clearing; none of the others showed any evidence of lysis.

Dilutions of phage were then spotted on their respective propagating strains spread over the surface of glucose serum agar plates with and without hvaluronidase; in both cases the titre was higher on the hyaluronidase plates than on the controls (see table).

The effect of the hyaluronic acid capsule un phage action can also be illustrated by using mucoid and non-mucoid variants of one strain. On a 'glossy' non-mucoid variant of type 6 , phage $A 6$ had a titre 